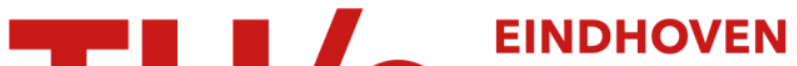 UNIVERSITY OF TECHNOLOGY
}

\section{Transparency and dichroism of ultra-drawn UHMW-PE films in the visible wavelength range}

\section{Citation for published version (APA):}

Bastiaansen, C. W. M., Schmidt, H. W., Nishino, T., \& Smith, P. (1993). Transparency and dichroism of ultradrawn UHMW-PE films in the visible wavelength range. Polymer, 34(18), 3951-3954.

https://doi.org/10.1016/0032-3861(93)90526-G

DOI:

10.1016/0032-3861(93)90526-G

Document status and date:

Published: 01/01/1993

\section{Document Version:}

Publisher's PDF, also known as Version of Record (includes final page, issue and volume numbers)

\section{Please check the document version of this publication:}

- A submitted manuscript is the version of the article upon submission and before peer-review. There can be important differences between the submitted version and the official published version of record. People interested in the research are advised to contact the author for the final version of the publication, or visit the $\mathrm{DOI}$ to the publisher's website.

- The final author version and the galley proof are versions of the publication after peer review.

- The final published version features the final layout of the paper including the volume, issue and page numbers.

Link to publication

\section{General rights}

Copyright and moral rights for the publications made accessible in the public portal are retained by the authors and/or other copyright owners and it is a condition of accessing publications that users recognise and abide by the legal requirements associated with these rights.

- Users may download and print one copy of any publication from the public portal for the purpose of private study or research.

- You may not further distribute the material or use it for any profit-making activity or commercial gain

- You may freely distribute the URL identifying the publication in the public portal.

If the publication is distributed under the terms of Article 25fa of the Dutch Copyright Act, indicated by the "Taverne" license above, please follow below link for the End User Agreement:

www.tue.nl/taverne

Take down policy

If you believe that this document breaches copyright please contact us at:

openaccess@tue.nl

providing details and we will investigate your claim. 


\title{
Transparency and dichroism of ultra-drawn UHMW-PE films in the visible wavelength range
}

\author{
C. Bastiaansen* $\dagger \ddagger$, H. - W. Schmidt $\$$, T. Nishino $\nmid \uparrow$ and P. Smith $\S$ \\ * DSM Research, PO Box 18, 6160 MD Geleen, The Netherlands \\ + Department of Polymer Chemistry, Eindhoven University of Technology, PO Box 513, \\ $6500 \mathrm{MB}$ Eindhoven, The Netherlands \\ $\S$ Materials Department, College of Engineering, University of California at Santa Barbara, \\ Santa Barbara, CA 93106, USA \\ - Department of Applied Chemistry, Kobe University, Rokko, Nada 657, Kobe, Japan \\ (Received 7 January 1993)
}

The optical properties in the visible wavelength range $(400-800 \mathrm{~nm})$ of solution-cast, ultra-drawn, ultra-high-molecular-weight polyethylene (UHMW-PE, $\bar{M}_{\mathrm{w}}>10^{6} \mathrm{~g} \mathrm{~mol}^{-1}$ ) films were investigated. UHMW-PE films, drawn 30 times at $125^{\circ} \mathrm{C}$, possess a rather low transmittance $(40-60 \%)$ in the visible wavelength range. However, highly transparent films with a transmittance exceeding $90 \%$ are obtained by applying a surface coating to the films. Dichroism in the visible wavelength range can be generated in drawn UHMW-PE films by incorporating dichroic dyes. Certain dichroic dyes were found to orient during solid-state drawing. Dichroic UHMW-PE films with a dichroic ratio of 30 and an order parameter of 0.91 were produced.

(Keywords: polyethylene; ultra-drawing; transmittance)

\section{Introduction}

The drawing behaviour of semicrystalline, flexible polymers in the solid state has been investigated extensively in the past ${ }^{1-7}$. The main objective of these studies was to generate a high degree of chain orientation and extension in order to approach the theoretical modulus and strength of polymers ${ }^{1-7}$. A variety of techniques was developed to produce high modulus and high strength structures. For instance, with the so-called gel-spinning process ${ }^{6,7}$, ultra-high-molecular-weight polyethylene (UHMW-PE, $\bar{M}_{\mathrm{w}}>10^{6} \mathrm{~g} \mathrm{~mol}^{-1}$ ) fibres can be produced, possessing a Young's modulus and tensile strength of, respectively, $>150 \mathrm{GPa}$ and $>4 \mathrm{GPa}$. Solid-state drawing was also used to modify other properties of semicrystalline, flexible polymers. It was shown that solid-state drawing enhances, for example, the barrier properties ${ }^{8,9}$, thermal conductivity ${ }^{8,10,11}$, electrical conductivity $^{12,13}$ and chemical resistance ${ }^{8}$ of semicrystalline polymers. More recently, the orientation of macromolecules incorporated as guests in solution-processed, drawn UHMW-PE has received considerable attention ${ }^{14-16}$. In this approach a second polymer is added to solutioncast/spun fibres or films in order to introduce an additional property such as electrical conductivity. Solid-state drawing was subsequently used to orient the host and guest polymer and both the mechanical and the electrical properties were enhanced.

The orientation of low-molecular-weight guest molecules in drawn semicrystalline polymers has been used to modify the optical properties of polymers in the visible wavelength range. For example, commercial polarizers are produced from drawn poly(vinyl alcohol) (PVAl) films ${ }^{17,18}$. H-sheet polarizers are produced by absorbing iodine in a pre-stretched PVAl sheet. Relaxation of

† To whom correspondence should be addressed orientation of the host polymer, during dipping of the PVAl sheet into the iodine solution, is prevented by fixing the PVAl film to a substrate such as cellulose acetate. During the absorption and drying procedure, the iodine molecules align parallel to the host macromolecules and anisotropic optical properties in the visible wavelength range are obtained.

The maximum attainable draw ratio of $\mathrm{PVAl}$ is relatively low compared to solution-cast UHMW-PE, and consequently the attainable degree of orientation of the host polymer is limited ${ }^{19,20}$. Remarkably, the relation between orientation of the host polymer and guest molecule has received little attention in the past, despite its commercial relevance. Intuitively one would expect that the orientation of the host polymer determines, at least to some extent, the visible light dichroism of polarizers. In this study, the orientation of dichroic dyes in ultra-drawn PEs is discussed ${ }^{20}$. An attempt is made to exploit the excellent solid-state drawing characteristics of linear PEs for the orientation of dichroic dyes. Preliminary results on the optical transparency and the attainable dichroic ratios will be presented.

\section{Experimental}

The UHMW-PE grade used in this study was Hostalen Gur 412 (Hoechst, Germany) which has a weight-average molecular weight of approximately $2 \times 10^{6} \mathrm{~g} \mathrm{~mol}^{-1}$. The dichroic dye (BASF, Germany) was a red anthraquinone dye with a melting temperature of $119^{\circ} \mathrm{C}$ and the following chemical structure:<smiles>C=CC(=O)OC(C)(C)CC(C)(C)Oc1cc(O)c2c(c1N)C(=O)c1ccccc1C2=O</smiles> 
The anthraquinone dye was dissolved in xylene $(0.03 \%$ $\mathrm{w} / \mathrm{v})$ at room temperature. Subsequently, $1.5 \% \mathrm{w} / \mathrm{v}$ UHMW-PE powder was added to the solution and the mixture was degassed at room temperature. A homogeneous solution was prepared by dissolving the polymer at $130^{\circ} \mathrm{C}$. The solutions were cast and quenched to room temperature. Subsequently, the solvent was evaporated at ambient conditions. Dry UHMW-PE films containing approximately $2 \% \mathrm{w} / \mathrm{W}$ of the dichroic dye were obtained.

Ultra-drawing of the dried, solution-cast UHMW-PE films was performed on thermostatically controlled hot shoes at $125^{\circ} \mathrm{C}$. The draw ratio was determined by measuring the displacement of ink-marks.

To avoid surface scattering during the optical measurements, a few drops of ethylene glycol were placed on the surface of the drawn films. The films were sandwiched between two glass slides. Transmission spectra of drawn films were measured with a Perkin-Elmer Lamda 9 instrument. The transmittance was measured in the wavelength range of $400-800 \mathrm{~nm}$. Polarized absorption spectra were obtained with a Perkin-Elmer Lamda 9 instrument. Two linear polarizers were placed in the measuring and reference beams and a background correction was executed. The sample was inserted in the measuring beam and, by rotating the sample, the absorption of the dichroic dye was maximized. After recording an absorption spectrum, the sample was rotated over a preset angle and additional absorption spectra were taken.

Polarized optical micrographs were recorded at a magnification of $50 \times$. Micrographs of drawn UHMW$\mathrm{PE}$ films containing the dichroic dye were taken with the polarization direction of the incident light parallel and perpendicular to the drawing direction.

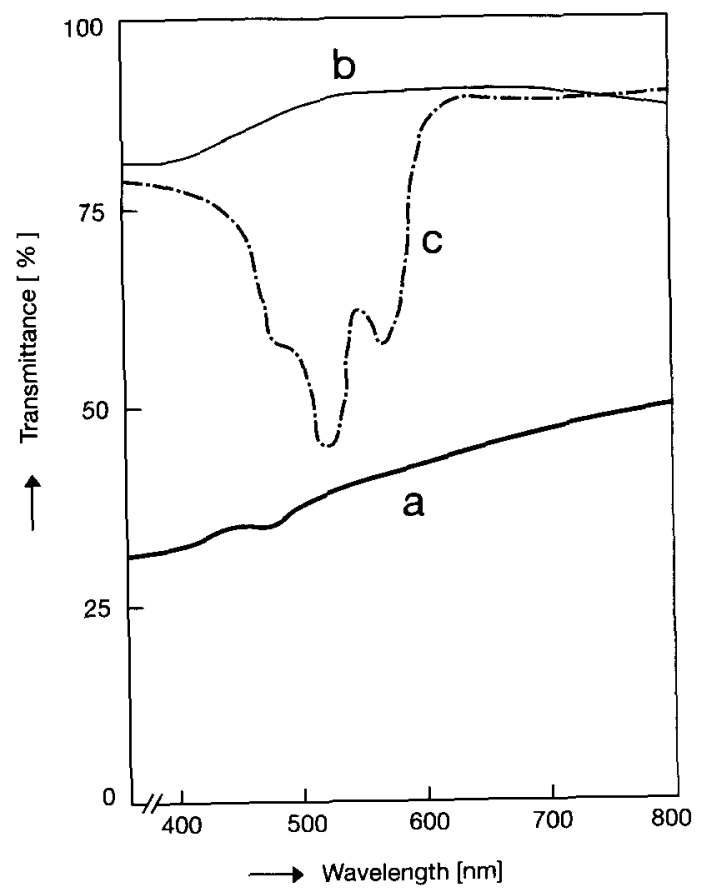

Figure 1 Transmission spectra of UHMW-PE films in the visible wavelength range (draw ratio 30 , draw temperature $125^{\circ} \mathrm{C}$ ): a, as-drawn film without dichroic dye; b, coated film without dichroic dye; $c$, coated film with $2 \% \mathrm{w} / \mathrm{w}$ anthraquinone dye

\section{Results and discussion}

In Figure 1, transmission spectra in the visible wavelength range $(400-800 \mathrm{~nm})$ of solution-cast, drawn UHMW-PE films are shown. The films were drawn at $125^{\circ} \mathrm{C}$ to a draw ratio of 30 and had a thickness of approximately $90 \mu \mathrm{m}$. The transmittance of the as-drawn UHMW-PE films is relatively low (spectrum a). The transmittance is drastically enhanced by coating with a low viscous fluid such as ethylene glycol (see Experimental section) and films with a high transmittance are obtained (spectrum b). Solution-cast, drawn UHMWPE films and fibres possess a highly fibrillar structure ${ }^{21}$ The drastic improvement in transmittance upon coating indicates that light scattering takes place mainly at the film surface. The internal fibrillar structure hardly influences the optical properties and, as a consequence, highly transparent films are obtained if surface scattering is suppressed by applying an appropriate coating. A transmission spectrum of a drawn, ethylene glycol coated UHMW-PE film containing $2 \% \mathrm{w} / \mathrm{w}$ of a red anthraquinone dye is also shown in Figure $I$ (spectrum c). The absorption of the dye is around 420-600 nm and, consequently, the transmittance of the drawn films is reduced by the absorption in this wavelength region. The transmittance of the drawn films above $600 \mathrm{~nm}$ remains high, which indicates that the high transparency of the drawn films is preserved after incorporation of dichroic dye.

The anthraquinone chromophore of the dichroic dye is aligned in the drawn films and generates optical anisotropy in the visible wavelength range. In Figure 2, polarized optical micrographs of dye-containing drawn UHMW-PE films are shown. The micrographs are taken with the polarization direction of the incident light perpendicular (a) and parallel (b) to the drawing direction. A substantial difference in colour intensity is observed, which indicates that the dichroic dye is oriented after drawing of the UHMW-PE films.

Polarized absorption spectra were recorded in order to quantify the visible light dichroism of the drawn UHMW-PE films (Figure 3). The absorption spectra were recorded as a function of the angle $(\theta)$ between the drawing direction and the polarization direction of the incident light. The measurements show that the light absorption is strongly dependent on the polarization direction which indicates, once more, that the films are highly anisotropic with respect to visible light absorption.

The dichroic ratio $(R)$ of the films can be calculated from the polarized absorption measurements using equation $(1)^{22-26}$ :

$$
R=A_{\text {par }} / A_{\text {perp }}
$$

where $A_{\text {par }}$ and $A_{\text {perp }}$ are the absorptions at a given wavelength $(520 \mathrm{~nm})$ measured, respectively, parallel and perpendicular to the drawing direction. The order parameter $(S)$ of the dye can be calculated with equation $(2)^{23-26}$;

$$
S=[R-1] /[R+2]\left[R_{0}+2\right] /\left[R_{0}-1\right]
$$

where $R_{0}$ is the dichroic ratio of a perfectly oriented dichroic dye. The term $\left[R_{0}+2\right] /\left[R_{0}-1\right]$ is a correction factor which is determined by the transition moment of the dichroic dye. The $R_{0}$ value of the anthraquinone dye used in this study is not known and therefore the correction factor was omitted in the calculations of the order parameter (equation (3)). This results in a systematic 

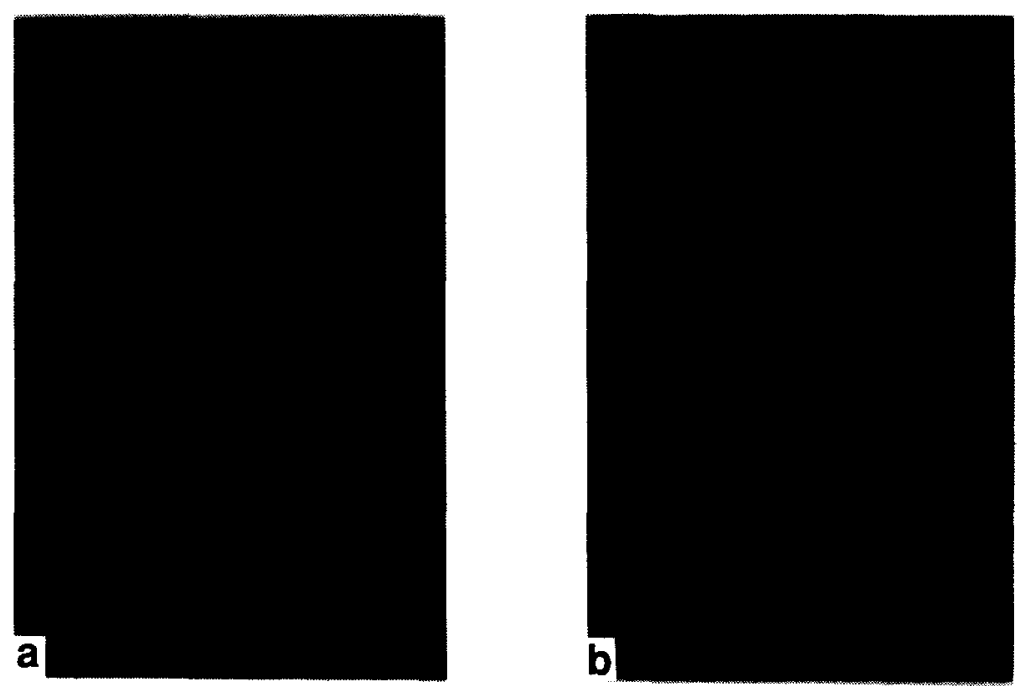

Figure 2 Optical micrographs of drawn UHMW-PE films (magnification $50 \times)\left(2 \% \mathrm{w} / \mathrm{w}\right.$ dichroic dye, draw ratio 30 , draw temperature $\left.125^{\circ} \mathrm{C}\right)$ : polarization direction of incident light perpendicular (a) and parallel (b) to the drawing direction

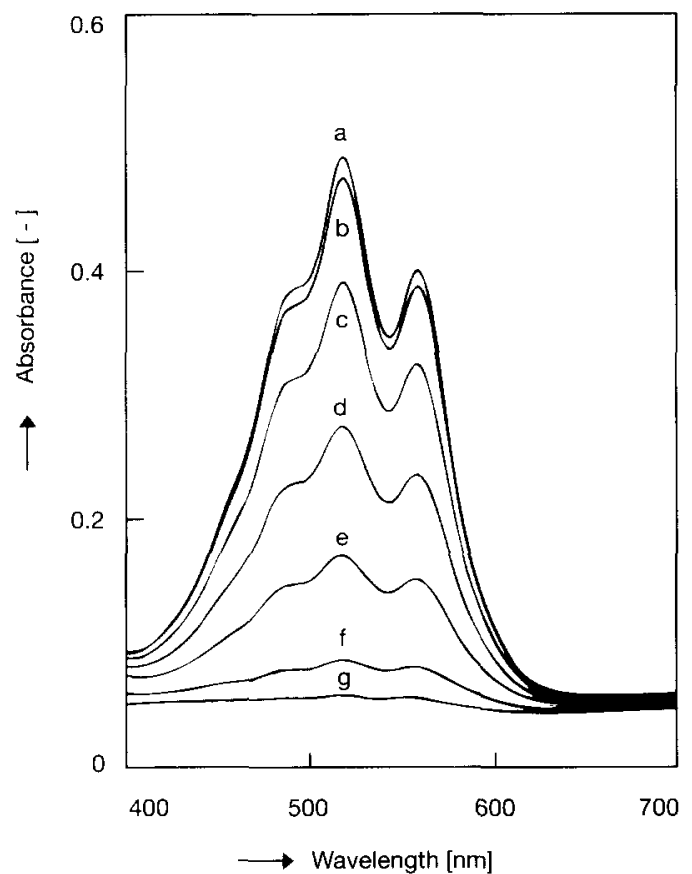

Figure 3 Polarized absorption spectra in the visible wavelength range of drawn UHMW-PE films ( $2 \% \mathrm{w} / \mathrm{w}$ dichroic dye, draw ratio 30 , draw temperature $125^{\circ} \mathrm{C}$ ) as a function of $\theta: \mathrm{a}, 0^{\circ} ; \mathrm{b}, 15^{\circ} ; \mathrm{c}, 30^{\circ} ; \mathrm{d}, 45^{\circ}$; $\mathrm{e}, 60^{\circ} ; \mathrm{f}, 75^{\circ} ; \mathrm{g}, 90^{\circ}$

underestimation of the order parameters.

$$
S=[R-1] /[R+2]
$$

In Figure 4, the dichroic ratio and order parameter of dye-containing, solution-cast, drawn films are plotted as a function of the draw ratio. It is shown that the dichroic ratio increases systematically with increasing draw ratio and that high dichroic ratios up to 30 are obtained, which corresponds to an order parameter of 0.91 . The dichroism of the same anthraquinone dye in macroscopically oriented nematic and smectic glasses of side-chain liquid crystal polymers was studied previously ${ }^{27,28}$. Maximum dye order parameters of 0.56 and 0.79 were found in nematic and smectic glasses, respectively. A comparison with the results of this study reveals that the enhanced

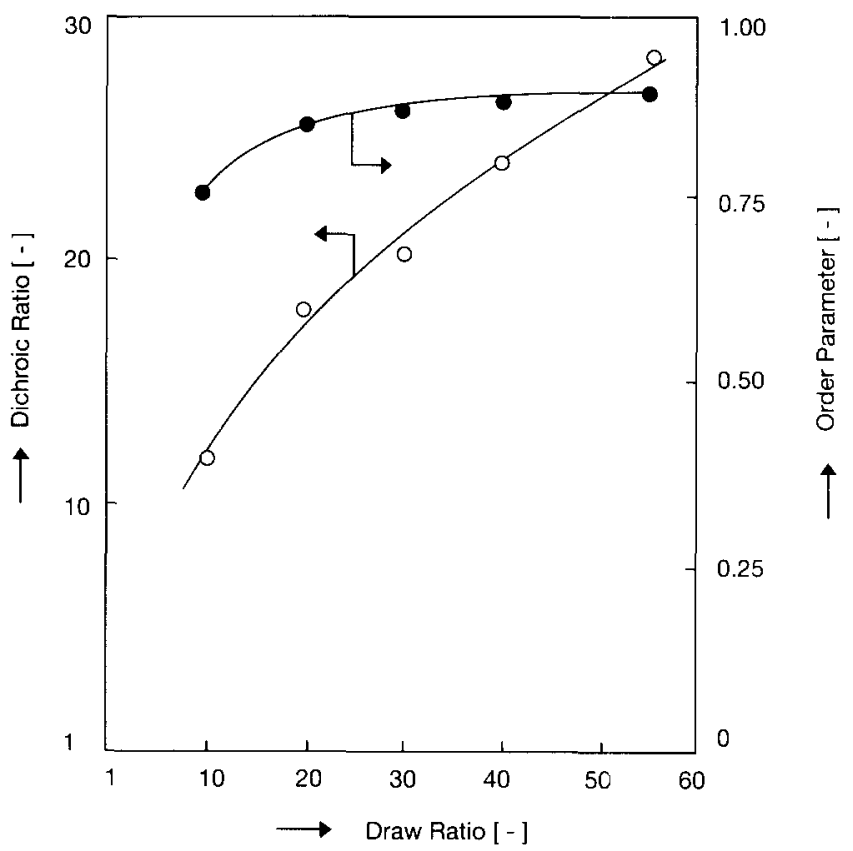

Figure 4 Dichroic ratio $(O)$ and order parameter $(0)$ of drawn UHMW-PE films $\left(2 \% \mathrm{w} / \mathrm{w}\right.$ dichroic dye, draw temperature $\left.125^{\circ} \mathrm{C}\right)$ as a function of draw ratio

orientation of solution-cast, drawn UHMW-PE films results in far superior dye order parameters.

In summary, the results of these investigations demonstrate that films with a high transmittance and a high level of optical anisotropy in the visible wavelength range can be produced from solution-cast, drawn UHMW-PE films. Apart from high transparency and dichroism, the UHMW-PE polarizers may have some additional advantages in comparison with PVAl polarizers. For instance, the durability of PVAl polarizers in a humid environment is rather poor, which is a severe limitation in some applications. UHMW-PE polarizers are hydrophobic and, consequently, enhanced durability is expected, especially in a humid environment ${ }^{29}$.

A variety of other issues concerning drawn, dichroic 
UHMW-PE films, such as the orientation mechanism of the dichroic dye and the relation between orientation of host polymer and guest molecule were hardly discussed. These topics are the subjects of ongoing experiments and will be discussed in future papers.

\section{Acknowledgements}

The work at UCSB was supported by the Materials Research Laboratory (National Science Foundation).

\section{References}

Peterlin, A. Colloid Polym. Sci. 1987, 364, 265

Peterlin, A. J. Appl. Phys. 1977, 48, 4099

Capaccio, G. and Ward, I. M. Nature (Phys. Sci.) 1973, 243, 143

Capaccio, G. and Ward, I. M. Polymer 1974, 15, 233

Capaccio, G., Crompton, T. A. and Ward, I. M. J. Polym. Sci., Polym. Phys. Edn 1976, 14, 1641

6 Smith, P., Lemstra, P. J., Kalb, B. and Pennings, A. J. Polym. Bull. $1979,1,733$

7 Smith, P., Lemstra, P. J. and Booij, H. C. J. Polym. Sci., Polym. Phys. Edn 1981, 19, 877

8 Ward, I. M. Adv. Polym. Sci. 1985, 1, 70

9 Holden, P., Orchard, G. A. and Ward, I. M. J. Polym. Sci., Polym. Phys. Edn 1981, 19, 335

10 Poulart, B., Chielens, J. C., Vandenhende, C., Issi, P. and Legras, L. Polym. Commun. 1990, 31, 148
11 Greig, D. in 'Developments in Oriented Polymers-1' (Ed. I. M. Ward), Applied Science Publishers, London, 1982

12 Gagnon, D., Capistran, J. D., Karasz, F. E. and Lenz, R. W. Polym. Bull. 1984, 12, 93

13 Moulton, J. and Smith, P. Polymer 1992, 33, 11, 2340

14 Hagler, T. W., Pakbaz, K., Moulton, J., Wudl, F., Smith, P. and Heeger, A. J. Polym. Commun. 1991, 32, 339

15 Moulton, J. and Smith, P. J. Polym. Sci., Polym. Phys. Edn 1992 30, 871

16 Tervoort, Y. PhD Thesis, Eindhoven University of Technology, Eindhoven, The Netherlands, 1991

17 Thulstrup, E. W. 'Spectroscopy with Polarized Light', Applied Science Publishers, London, 1988

18 Mizoguchi, R., Kobayashi, K., Shimomura, T. and Kobayashi, S. Displays 1983, 201

19 Schellekens, R. and Bastiaansen, C. W. M. J. Appl. Polym. Sci. 1991, 43, 2311

20 Bastiaansen, C. W. M., PhD Thesis, Eindhoven University of Technology, Eindhoven, The Netherlands, 1991

21 Smook, J., Hamersma, W. and Pennings, A. J. J. Mater. Sci. 1984, 19, 1359

Schmidt, P. G. J. Polym. Sci. 1963, 1A, 1271

Schnell, G. Ergeb. Exakten Naturwissensch. 1959, 31, 270

Zbinden, R. 'Infrared Spectroscopy of Polymers', New York, 1964

25 Koenig, J. L., Cornell, S. W. and Witenhafer, D. E. J. Polym. Sci. $A-2$ 1967, 5, 301

26 Read, B. E. and Stein, R. S. Macromolecules 1968, 1, 116

27 Ringsdorf, H., Schmidt, H.-W., Baur, G., Kiefer, R. and Windscheid, F. Liq. Cryst. 1986, 1, 319

28 Schmidt, H.-W. Angew. Chem. Adv. Mater. 1989, 101, 964

29 Bastiaansen, C. W. M. DSM Stamicarbon, Pat. Appl. Nl 9101008,1991 